Sains Malaysiana 48(3)(2019): 555-559

http://dx.doi.org/10.17576/jsm-2019-4803-07

\title{
Successful and Efficient DNA Extraction from Processed Pangolin Scales
}

(Kejayaan dan Kecekapan Pengekstrakan DNA daripada Sisik Tenggiling Terproses)

\author{
Xuan Cai, Hao-Ting Ye, En-Wei Tian, FAng Li, Chan Li, Yao-Jun Yang, Chun-Sheng LiU \& Zhi ChaO*
}

\section{ABSTRACT}

A successful method for total DNA extraction from crude and processed pangolin scales was established. After pretreatment in the soaking solution for cleansing, the scales were prepared into fine powders and treated with PBS buffer containing $0.1 \%$ collagenase and $0.1 \%$ trypsin for $24 \mathrm{~h}$, followed by digestion with proteinase $\mathrm{K}$ at $55^{\circ} \mathrm{Cfor} 120 \mathrm{~h}$. Phenol-chloroform extraction was used to obtain the total DNA. PCR amplification for mitochondrial cytochrome b (cytb) gene was successful using the extracted DNA as the template, and sequencing of the amplified fragments confirmed Manis origin of the scale samples. With an efficiency up to $100 \%$, this method is expected to provide a powerful tool in molecular identification of processed as well as crude pangolin scales.

Keywords: DNA extraction; Manis; processed pangolin scales

ABSTRAK

Kaedah berkesan untuk pengekstrakan DNA total daripada sisik tenggiling mentah dan terproses telah berjaya dihasilkan. Selepas pra-rawatan dengan cara merendam di dalam larutan untuk pembersihan, sisik disediakan dalam bentuk serbuk halus dan dirawat dengan penimbal PBS yang mengandungi $0.1 \%$ kolagenase dan tripsin $0.1 \%$ selama 24 jam diikuti penghadaman oleh proteinase $\mathrm{K}$ pada $55^{\circ} \mathrm{C}$ selama 120 jam. Pengekstrakan fenol-kloroform telah digunakan untuk mendapatkan DNA total. Amplifikasi PCR untuk gen mitokondria sitokrom b (cytb) telah berjaya dengan menggunakan ekstrak DNA sebagai templat dan penjujukan serpihan teramplifikasi membuktikan sampel sisik berasal daripada Manis. Dengan kadar kecekapan sehingga 100\%, kaedah ini dijangka menjadi suatu alat berkesan untuk mengenal pasti molekul sisik terproses serta mentah tenggiling.

Kata kunci: Manis; pengekstrakan DNA; sisik tenggiling terproses

\section{INTRODUCTION}

In traditional Chinese medicine (TCM), the scales of Chinese pangolin (Manis pentadactyla L.) are used as a precious medicinal material for treatment of amenorrhea, abdominal mass, obstruction of milk secretion, carbuncles, arthralgia, limb numbness and spasm (Chinese Pharmacopoeia Commission 2015). With the rapid reduction of the wild source and difficulties in the breeding of Chinese pangolin (Thapa 2013), the commercial supply of pangolin scales has been substantially lowered, which causes the sharp increase in its price in recent years and the emergence of the malpractice of adulteration.

The common pangolin species used for adulteration of Chinese pangolin include Manis javanica (Sunda pangolin) and $M$. crassicaudata (Indian pangolin) from Southeast and South Asia, Phataginus tricuspis (= Manis tricuspis, tree pangolin) and Smutsia gigantea (= Manis gigantea, Giant pangolin) from Africa (Liu et al. 2011; Yin et al. 2016). The parts from some irrelevant species are also used for adulteration, including hoof coverings of pigs, cattle or sheep, which severely jeopardizes the drug safety of pangolin scales and the normal practice of TCM, and lowers the confidence in the drug market as well.
Moreover, the over-capture and smuggling of pangolins put them on the verge of extinction. The IUCN Red List of Threatened Species (2017) listed Chinese pangolin and Sunda pangolin as 'Critically Endangered', and other pangolin species as 'Endangered' or 'Vulnerable'. In 2017, all the eight species of pangolin were listed in Appendix I issued by the Convention on International Trade in Endangered Species of Wild Fauna and Flora (CITES). Accurate identification of scales is absolutely necessary for conservation and sustainable utilization of pangolins.

The identification of genuine pangolin scales against these counterfeits relies conventionally on macroscopic inspection (Liu et al. 2017, 2014, 2011; Wu et al. 2015). But the size, color and texture of pangolin scales can vary with age and living environment of pangolins and with the positions where the scales are taken ( $\mathrm{Su}$ et al. 1994). With such great intraspecific variations and few recognizable interspecific characteristics, the pangolin scales are difficult to be identified without sufficient experiences and expertise.

DNA molecular markers have now been widely used for identification of Chinese medicinal materials (Coutinho et al. 2015; Huang et al. 2017). These molecular 
markers are expected to provide an accurate and objective molecular approach to authentication and identification of pangolin scales and its counterfeits. For molecular identification, the prerequisite work is to obtain sufficient high quality DNA from the scales. But extracting DNA from the pangolin scales is rather difficult due to the high keratinization of the scales. In 2013, Xing et al. reported a method for DNA extraction from 'clean' scales (free of residual skin tissue) and skin stripped from pangolin specimen based on protein $\mathrm{K}$ digestion; but according to our experience, the success rate and reproducibility of this method need to be improved. In a later study, Jia et al. (2014) described an alternative method for extracting genomic DNA from the residual skin tissue on the ventral surface of the scales for DNA barcoding of pangolin scales. More recently, successful DNA extraction from pangolin scales and the remaining skin tissue attached to the scales were reported using Promega Wizard ${ }^{\circledR}$ SV Genomic DNA Purification System (Mwale et al. 2017) or QIAamp ${ }^{\circledR}$ DNA Investigator Kit (Yin et al. 2017); but it is not clear whether these methods can be successfully applied to clean scales without residual skin tissues, and how the efficiency (success rate) of these methods is. So far, the attempts of DNA extraction from processed scales all remained unsuccessful.

In this study, we aimed to establish an improved method for DNA extraction from pangolin scales, both crude and processed, to increase the efficiency of DNA extraction for subsequent PCR-based identification of the scales.

\section{MATERIALS AND METHODS}

\section{PANGOLIN SCALE SAMPLES}

Pangolin scale samples, including 3 crude samples (labeled as A, B, and C) and 3 processed samples (DF), were purchased from Zhongliang Pharmaceutical Co. Ltd., a local drug trading company authorized for supplying pangolin scales in Guangzhou, Guangdong Province, China. All the samples were macroscopically identified based on their morphological characters (Liu et al. 2017; Wu et al. 2015) by Dr. Zou Jiejian, Guangdong Wildlife Rescue Center. The vouchers were kept in herbal medicine museum of Southern Medical University (Table 1).

\section{DNA EXTRACTION FROM PANGOLIN SCALE SAMPLES}

To extract genomic DNA from the crude scale samples, the scales were first soaked in anhydrous ethanol for 12 h. Ethanol was replaced every $3 \mathrm{~h}$, with the container constantly shaken slightly on an oscillator. After ethanol treatment, the scales were transferred to a vessel containing deionized water and immersed for another $12 \mathrm{~h}$. After drying at $60^{\circ} \mathrm{C}$, the cleaned scales were irradiated with ultraviolet light for $30 \mathrm{~min}$ on each side. The scales were then milled into fine powder, and for each sample, precisely $0.4 \mathrm{~g}$ of the powder was weighed and treated with $1 \mathrm{~mL}$ of the soaking buffer $(10 \mathrm{mmol} / \mathrm{L}$ Tris-HCl, $0.2 \mathrm{~mol} / \mathrm{L}$ EDTA, and $50 \mathrm{mmol} / \mathrm{L} \mathrm{NaCl} ; \mathrm{pH} 8.0$ ) in a $1.5 \mathrm{~mL}$ Eppendorf tube overnight at $4^{\circ} \mathrm{C}$. After centrifugation at $5000 \mathrm{r} / \mathrm{min}$ for $10 \mathrm{~min}$, the supernatant was removed and $1 \mathrm{~mL}$ of PBS containing $0.1 \%$ collagenase and $0.1 \%$ trypsin was added in the tube for digestion of the scale powder at $37^{\circ} \mathrm{C}$ for 24 $\mathrm{h}$. After the digestion, the supernatant was again discarded after centrifugation (10000 r/min, $10 \mathrm{~min})$, and $1 \mathrm{~mL}$ of the digestion buffer (pH8.0) containing $10 \mathrm{mmol} / \mathrm{L}$ Tris$\mathrm{HCl}, 50 \mathrm{mmol} / \mathrm{L} \mathrm{NaCl}, 2 \% \mathrm{sDS}, 1 \mathrm{mmol} / \mathrm{L}$ DTT, $1 \mathrm{mmol} / \mathrm{L}$ $\mathrm{CaCl}_{2}$ and $100 \mu \mathrm{L}$ protease $\mathrm{K}(10 \mathrm{~g} / \mathrm{L})$ was added, and the tube was water-bathed at $55^{\circ} \mathrm{C}$ for $120 \mathrm{~h}$ with gentle shaking every $4 \mathrm{~h}$. The supernatant was collected after centrifugation (10000 r/min, $10 \mathrm{~min}$ ). DNA was extracted from the supernatant using routine phenol-chloroform method. The protocols for DNA extraction from processed pangolin scales were almost identical to those for the crude scales, only the time for protease $\mathrm{K}$ digestion was shortened to $72 \mathrm{~h}$. The quantity and quality of the extracted DNA was determined with a Nanodrop ND-2000 spectrophotometer (ThermoScientific, USA) by measuring the absorbance at $260 \mathrm{~nm}\left(A_{260}\right)$ and the ratio of $A_{260} / A_{280}$

\section{PCR AMPLIFICATION AND DNA SEQUENCING}

The universal primers L 14841 (5'-CCATCCAACATCTCAGCATGATGAAA-3') and H15149 (5'-GCCCCTCAGAATGATATTTGTCCTCA-3') were used to amplify the mitochondrial cytochrome b (Cyt b) gene fragment. PCR reactions were carried out with an Applied Biosystems 2720 Thermal Cycler (Applied Biosystems, Carlsbad CA, USA) in a total volume of $25 \mu \mathrm{L}$ containing $12.5 \mu \mathrm{L}$ of $2 \times$ Taq PCR MasterMix (Tiangen Biotech Co., Ltd. Beijing, China), the forward and reverse primers $(2.5 \mu \mathrm{mol} / \mathrm{L}, 1 \mu \mathrm{L}$ of each $), 1 \mu \mathrm{L}$ of the genomic

TABLE 1. Crude (A-C) and processed (D-F) samples of pangolin scales used in the study and the results of species identification

\begin{tabular}{cccc}
\hline Sample number & Original species & BLAST identification results & Similarity \\
\hline A & Manis pentadactyla & Manis pentadactyla & $99 \%$ \\
B & Manis pentadactyla & Manis pentadactyla & $100 \%$ \\
C & Manis tricuspis & Manis tricuspis & $100 \%$ \\
D & Manis gigantea & Manis gigantea & $100 \%$ \\
E & Manis javanica & Manis javanica & $97 \%$ \\
F & Manis javanica & Manis javanica & $97 \%$ \\
\hline
\end{tabular}


DNA, and $9.5 \mu \mathrm{L}$ of $\mathrm{ddH}_{2} \mathrm{O}$. Thermal cycling was performed with an initial denaturing at $94^{\circ} \mathrm{C}$ for $10 \mathrm{~min}$, followed by 35 cycles of $94^{\circ} \mathrm{C}$ for $30 \mathrm{~s}, 45^{\circ} \mathrm{C}$ for $45 \mathrm{~s}$, and $72^{\circ} \mathrm{C}$ for $30 \mathrm{~s}$, with a final extension at $72^{\circ} \mathrm{C}$ for $10 \mathrm{~min}$ and chilling to $4^{\circ} \mathrm{C}$. A blank control was set by substituting $\mathrm{ddH}_{2} \mathrm{O}$ for the template DNA. The PCR products $(5 \mu \mathrm{L})$ were subjected to $1.2 \%$ agarose gel electrophoresis and visualized with ethidium bromide staining under UV.

After purification, the products were sequenced in both directions by Invitrogen Biotechnology (Shanghai) Co., Ltd. The DNA sequences were manually edited and aligned using the software BioEdit and Clustal X. The aligned sequences were used to identify the species of origin using a forward sequence BLAST search, and the results were confirmed with the reverse sequence BLAST search results. Furthermore, a bootstrap (1000 replicates) neighbor-joining ( $\mathrm{NJ}$ ) tree for these sequences and the counterpart sequences of Manis species in GenBank was constructed based on the K2P distances to validate the identification results.

\section{RESULTS}

Genomic DNA was successfully extracted from 6 pangolin scale samples. The DNA concentration in the extracts ranged from 23.3 to $59.0 \mathrm{ng} / \mu \mathrm{L}$ with an $A_{260} / A_{280}$ ratio ranging from 1.65 to 2.03 .

Using the primers L14841 and H15149, we amplified a specific fragment ( $307 \mathrm{bp}$ ) of Cytb gene from mammalian mitochondrial DNA genome. For all the 6 samples, electrophoresis of the PCR product yielded a distinct single band about 350 bp in length (Figure 1), suggesting successful amplification of the target gene fragment. The blank control showed no amplified fragment, indicating that no exogenous DNA contamination occurred during the amplification.

BLAST search results of the aligned sequence of Cytb amplicons showed bootstrap values of $100 \%$ with each original species (Figure 2), which confirmed the correctness of the template DNA and thus validated the DNA extraction method.

\section{DISCUSSION}

DNA extraction is the first step for identification of Chinese medicinal materials based on DNA molecular markers. Pangolin scales are characterized by its richness in keratin and collagen, and these proteins must be fully digested before the DNA can be successfully extracted from the scales. The formula of the digestion buffer and the digestion time are the key factors that substantially affect the effect of digestion. Xing et al. (2013) increased the concentration of SDS in the digestion buffer and added a reductant (1,4-dithiothreitol, DTT) to destroy the connection between the cell and the nuclear membrane, which accelerated the breach of the denaturalized cell membrane of the cells in the scale. This helps to maintain a reductive environment for stabilizing the enzymatic activity of proteinase $\mathrm{K}$, and opens the overabundant disulfide bond in keratin to improve the efficiency of keratin digestion. In addition, they also added $1 \mathrm{mmol} / \mathrm{L} \mathrm{CaCl}_{2}$ into the digestion buffer to maintain the catalytic activity of proteinase $\mathrm{K}$. Through these measures, they successfully extract the total DNA from the taxidermal specimens, residual dry skin tissues on the ventral surface of pangolin scales, and pangolin scales free of residual skins; but the efficiency of DNA extraction and amplification from clean pangolin scales remained poor, much lower than that from ventral residual skin tissues.

We presume that the low efficiency of the method of Xing et al. (2013) might result from insufficient digestion of keratin and collagen, as well as DNA degradation caused by DNase during the extraction. Inspired by the study of Lan et al. (1995), who reported successful DNA extraction from fur specimens of Muntiacus spp., we modified the DNA extraction procedure by adding a step of $0.1 \%$ collagenase and $1 \%$ trypsin treatment for $24 \mathrm{~h}$ prior to

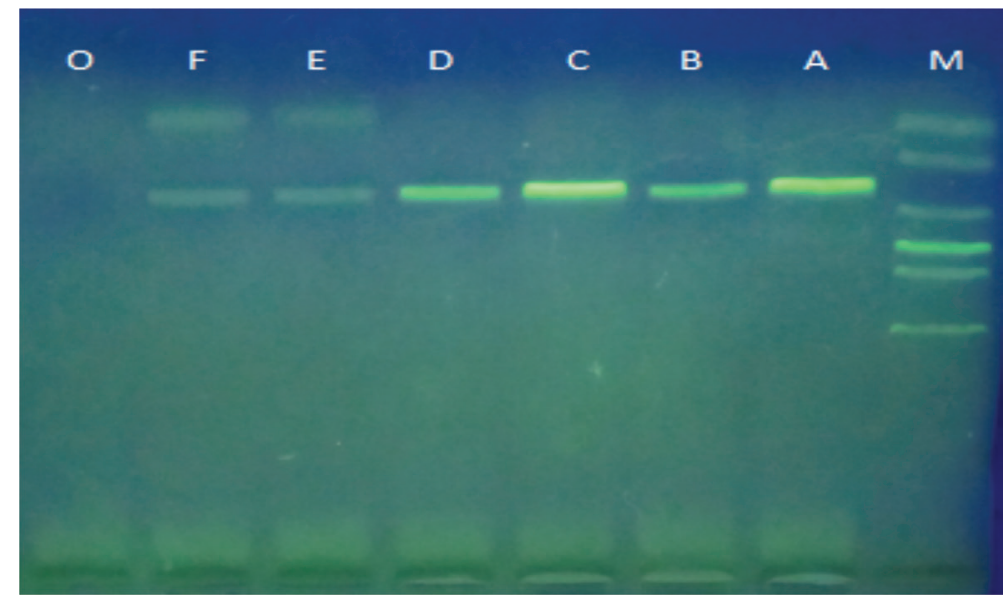

FIGURE 1. Agarose gel electrophoresis of $c y t b$ fragments amplified from pangolin scales M, 100bp DNA ladder; A-C, crude scale samples, Manis pentadactyla, M. pentadactyla, M. tricuspis, respectively; D-F, processed scale samples, $M$. gigantea, $M$. javanica, $M$. javanica, respectively; O, negative control 


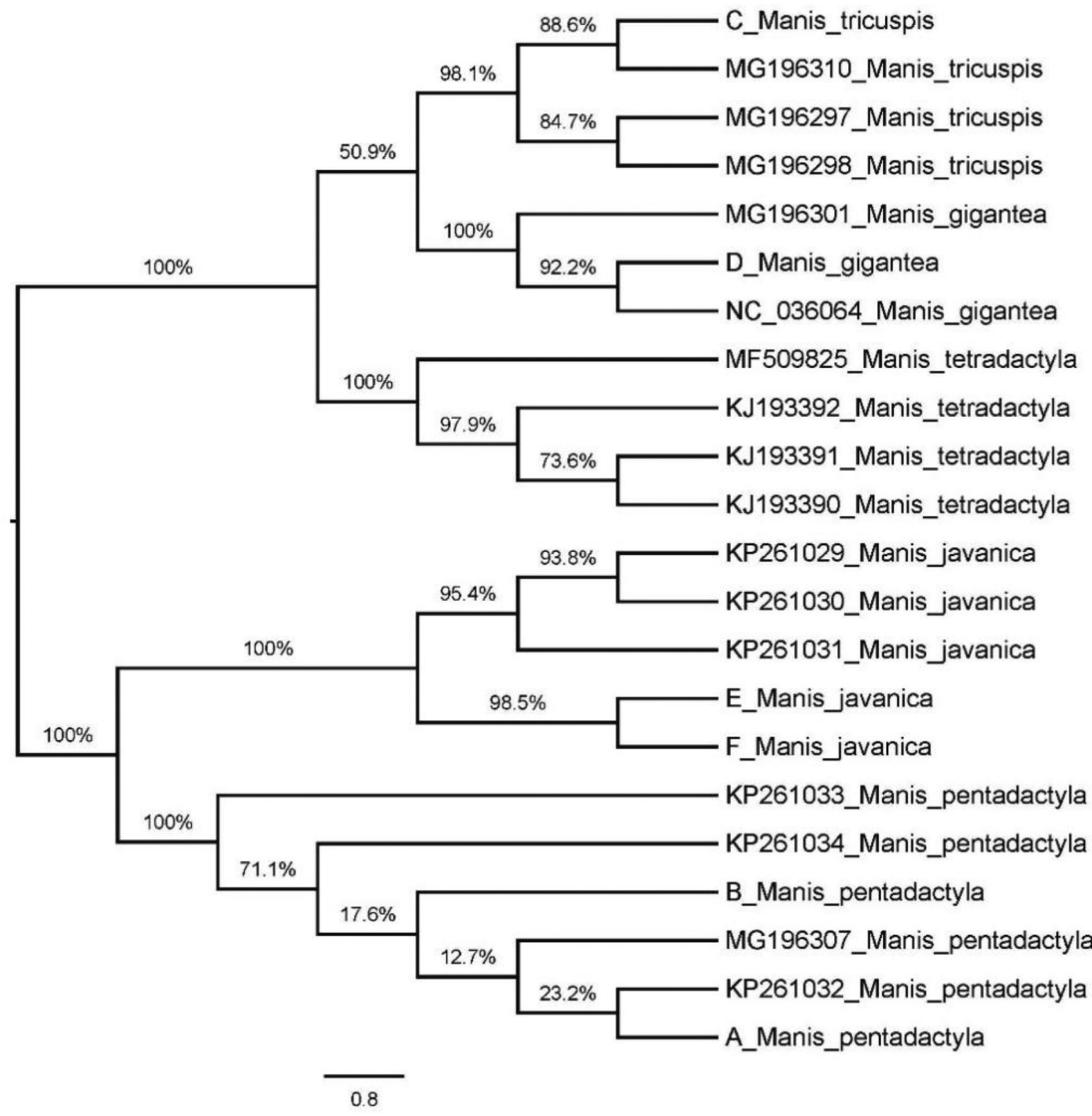

FIGURE 2. Neighbor-joining tree based on cytb sequences derived from pangolin scales (1000 bootstrap replicates, Model = Kimura-2-Parameter) A-F, pangolin scale samples; MG196310, etc. accession number of $c y t b$ gene of pangolins downloaded from GenBank

proteinase K digestion. Both collagenase and trypsin were used at relatively high concentrations to hydrolyze collagen as much as possible and minimize DNA degradation by DNase. We further increased the amount of proteinase $\mathrm{K}$ to over 3 times as much as that used by Xing et al. (2013) and extended the digestion time to $72 \mathrm{~h}$ for crude pangolin scales and further to $120 \mathrm{~h}$ for processed ones. As a result, we obtained a DNA extraction success rate of $100 \%$ from all the samples.

Appropriate sample pretreatment is also important to successful extraction of high quality DNA by preventing or reducing the possibility of exogenous DNA contamination. Soaking and washing of the samples with anhydrous ethanol and deionized water and subsequent ultraviolet light irradiation can remove the contaminants on the surface as well as the liposoluble and water-soluble PCR inhibitors in the sample, and completely cross-link exogenous DNA on the scale surface. DNA degradation occurs mainly when the sample is soaked and softened
(Lan et al. 1995). The soaking buffer containing a high concentration of EDTA can inhibit the activity of DNase, thus effectively prevents the degradation of DNA. At the same time, EDTA chelating can remove heavy metal ions to improve the quality of the extracted DNA.

Our method is efficient and cost-effective for DNA extraction from pangolin scales. Shi et al. (2004) and Xing et al. (2013) described their protocols for extracting DNA from the scales of Chinese alligator (Alligator sinensis) and pangolin, respectively, using 0.5-1.0 $\mathrm{g}$ of the scale samples. By comparison, we used a more economic amount of the scale sample of $400 \mathrm{mg}$ and the DNA extraction protocols can be completed at a lower cost than those using commercial kits (Yin et al. 2017) but result in a greater yield of DNA from the scales. Nevertheless, the operation should be as gently as possible to avoid break of DNA strands during the whole DNA extraction process.

The nails of pigs, sheep, cattle, and yak are the common adulterants of pangolin scales in the market. 
They share similar physical and chemical characteristics with pangolin scales with high keratinization. According to our experience, the method we report herein is also applicable to these samples, thus providing a practical technical solution for DNA extraction from pangolin scale and its adulterants.

\section{CONCLUSION}

We established a modified method for DNA extraction from both crude and processed pangolin scales with a successful rate of $100 \%$. The quality and quantity of DNA extracted well met the requirements of the following procedures of DNA amplification and sequencing. This method provides a reliable technical support for molecular authentication and identification of pangolin scales.

\section{ACKNOWLEDGEMENTS}

The study was supported by Special Fund for TCM Research in the Public Interest of China: Quality Guarantee System of Chinese Herbal Medicines (No. 201507002).

\section{REFERENCES}

Chinese Pharmacopoeia Commission. 2015. Pharmacopoeia of the People's Republic of China. Vol. 1: 268. China Medical Science \&Technology Press: Beijing, China.

CITES. 2017. Convention on international trade in endangered species of wild fauna and flora. https://cites.org/sites/default/ files/eng/app/2017/E-Appendices-2017-10-04.pdf.

Coutinho, M.D.F., Still, D.W., Lum, M.R. \& Hirsch, A.M. 2015. DNA-based authentication of botanicals and plant-derived dietary supplements: Where have we been and where are we going? Planta Medica 81: 687-695.

Huang, L.Q., Yuan, Y., Jiang, C. \& Tian, X.X. 2017. Strategy on molecular authentication of animal medicines. Modern Chinese Medicine 19: 1-10.

IUCN. 2017. The IUCN Red List of Threatened Species. Version 2017-2. http://www.iucnredlist.org. Accessed on 9 November 2017

Jia, J., Zhang, H.Y., Chen, J., Liu, D., Yao, H., Qian, Q.N. \& Zhang, H. 2014. Molecular identification of Manis pentadactyla using DNA barcoding. China Journal of Chinese Materia Medica 39: 2212-2215.

Lan, H., Wang, W. \& Shi, L.M. 1995. PCR analysis of DNA from fur specimens of muntjacs (Muntiacus). Zoological Research 16: 146-152.

Liu, C.H., Zhang, J., Kang, S., Liu, T.S. \& Zhao, J. 2014. Identification of the scales of Manis pentadactyla, $M$. tricuspis and their adulterants. Journal of Chinese Medicinal Materials 37: 1178-1182.
Liu, S., Zhang, H.F., Liu, X.M., Zhu, Y. \& Cui, X.B. 2017. Identification of processed pangolin scales from 4 different Manis species. Journal of Chinese Medicinal Materials 40: 585-588.

Liu, X.Q., Peng, J.J., Gao, S.F., Yu, D.M., Gao, L.F., Wang, L.L., Hu, S.J. \& Fu, M.L. 2011. Smuggling trade overview, species identification and morphological comparison of pangolin. Practical Forestry Technology 41: 11-14.

Mwale, M., Dalton, D.L., Jansen, R., De Bruyn, M., Pietersen, D., Mokgokong, P.S. \& Kotzé, A. 2017. Forensic application of DNA barcoding for identification of illegally traded African pangolin scales. Genome 60: 272-284.

Shi, Y., Wu, X.B., Yan, P. \& Zhao, Z. 2004. A method for DNA extraction from tannage and scales of Chinese alligator Alligator sinensis. Acta Zoologica Sinica 50: 297-301.

Su, B., Liu, R.Q., Wang, Y.X. \& Shi, L.M. 1994. Genetic diversity in the Chinese pangolin (Manis pentadactyla) inferred from protein electrophoresis. Biochemical Genetics 32: 343-349.

Thapa, P. 2013. An overview of Chinese pangolin (Manis pentadactyla): Its general biology, status, distribution and conservation threats in Nepal. The Initiation 5: 164-170.

Wu, Z.Y., Chao, J.G. \& Liu, X. 2015. Pharmacognostical studies on four sources of Manis spp. Research and Practice on Chinese Medicines 29: 25-28.

Xing, Y.L., Peng, J.J., Hu, H.J., Yu, D.M., Zhang, L.B. \& Yu, B.C. 2013. Extraction and amplification of DNA from pangolin specimen and scales. Chinese Journal of Zoology 48: 49-57.

Yin, Y., Liu, X., Wang, B., Gao, L.H. \& Zhang, X.N. 2017. DNA molecular identification of Manis pentadactyla. China Journal of Chinese Materia Medica 42: 2078-2084.

Xuan Cai, Hao-Ting Ye, En-Wei Tian, Fang Li, Chan Li \& Zhi Chao*

School of Traditional Chinese Medicine

Southern Medical University

Guangzhou 510515

China

Yao-Jun Yang \& Chun-Sheng Liu

School of Chinese Materia Medica

Beijing University of Chinese Medicine

Beijing 100029

China

*Corresponding author; email: chaozhi@smu.edu.cn

Received: 9 March 2018

Accepted: 14 November 2018 